Symptoms of bronchial hyperreactivity and asthma in relation to environmental factors. Arch Dis Child 1988;63:473-8.

18 Lunn JE, Knowelden J, Roe JW. Patterns of respiratory illness in Sheffield junior schoolchildren-a follow up study. Br f Prev Soc Med 1970;24:223-8. 9 Ware JH, Ferris BG Jr, Dockery DW, Spengler JD, Stram DO, Speizer FE. Effects of ambient sulfur oxides and suspended particles on respiratory health of pre-adolescent children. Am Rev Respir Dis 1986;133:834-42.

20 Braun-Fahrländer C, Ackermann-Liebrich U, Schwartz J, Rutishauser M, Gnehm HP, Wonner HU. Air pollution and respiratory symptoms in preschool children. Am Rev Respir Dis 1992;148:42-7.

21 Molfino NA, Wright SC, Katz I, Tarlo S, Silverman F, McClean PA, et al. Effect of low concentrations of ozone on inhaled allergen responses in asthmatic subjects. Lancet 1991;338:199-203.

22 Ferris BG. Epidemiology standardization project. Am Rev Respir Dis 1978;118 (suppl):7-53.

23 Nicolai T, Mutius E von, Reitmeir P, W jst M. Reactivity to cold air hyperventilation in normal and asthmatic children in a survey of 5697 school hyperventilation in normal and asthmatic children in a survey

24 Fleiss JL. Statistical methods for rates and proportions. New York: John Wiley, 1980.

25 SAS. Statistical analysis system. Version 6.06. Cary, North Carolina: SAS, 1990.

26 Steinbrück P, Herrmann H, Landmann H. Empfehlungen der Problemkeinbrück $\mathrm{P}$, Herrmann $\mathrm{H}$, Landmann $\mathrm{H}$. Empfehlungen der Problem-
kommion für Lungenkrankheiten und Tuberkulose zur Definition von chronischer Bronchitis, Asthma bronchiale und Lungenemphysem. Monatsschrift für Lungenkrankheiten und Tuberkulose Bekämpfung 1969;12: 289-98.

27 Logan WPD. Mortality in London fog incident. Lancet 1953;i:336-8.

\section{Medical management of missed abortion and anembryonic pregnancy}

\author{
H El-Refaey, K Hinshaw, R Henshaw, \\ N Smith, A Templeton
}

Miscarriage is the most common complication of pregnancy and probably accounts for around 50000 inpatient admissions in the United Kingdom each year. Generally, its management has changed little with time. Recently developments in non-surgical treatment, refined in induced abortion, offer an opportunity to improve management and to remove the need for surgery and anaesthesia. We report our initial experience of the use of mifepristone (an antiprogesterone) and misoprostol (a synthetic analogue of prostaglandin $\mathrm{E}_{1}$ ) in the management of missed abortion and anembryonic pregnancy (gestation sac present but no developing embryo).

\section{Patients, methods, and results}

Sixty women with a diagnosis of missed abortion or anembryonic pregnancy equivalent to 13 weeks' gestation or less were recruited after counselling. Twenty five of the women had been referred for ultrasound scanning because of bleeding in early pregnancy, while in the remainder the diagnosis had been made on routine scanning when they booked. Patients in whom an incomplete abortion was diagnosed were not included.

Each patient was given a single oral dose of mifepristone $600 \mathrm{mg}$ and was admitted to the gynaecological ward as an outpatient $36-48$ hours later, when misoprostol $600 \mu \mathrm{g}$ was given orally in a divided dose (400 $\mu \mathrm{g}$ and, two hours later, $200 \mu \mathrm{g}$ ). The patient's pulse, blood pressure, and temperature were recorded hourly, as were any side effects and requests for analgesia. If the products of conception were not expelled and verified within four hours vaginal ultrasonography was performed. If the gestation sac was not seen and bleeding had occurred the procedure was considered to have been successful, but if not the patient was offered evacuation of the uterus under general anaesthesia. All patients were reviewed 10-14 days later.

The median age of the 60 women was 27 (range 15-44), and the median duration of amenorrhoea was $71(42-110)$ days. Twenty nine patients were diagnosed as having anembryonic pregnancies and the remaining 31 as having had a missed abortion. One of the patients thought to have an anembryonic pregnancy was
28 Gore AT, Shaddick CW. Atmospheric pollution and mortality in the county of London. Br f Prev Soc Med 1968;12:104-13.

29 Lunn JE, Knowelden J, Handyside AJ. Patterns of respiratory illness in Sheffield infant school children. Br J Prev Soc Med 1967;21:7-16.

30 Dodge R, Solomon P, Moyers J, Hayes C. A longitudinal study of children exposed to sulfur oxides. Am F Epidemiol 1985;121:720-36.

31 Dockery DW, Speizer FE, Stram DO, Ware JH, Spengler JD, Ferris BG. Effects of inhalable particles on respiratory health of children. $\mathrm{Am} R e$ Respir Dis 1989;139:587-94.

32 Koenig JQ, Morgan MS, Horike M, Pierson WE. The effects of sulfur dioxides on nasal and lung function in adolescents with extrinsic asthma.W f Allergy Clin Immunol 1985;76:813-8.

33 Sheppard D, Wong WS, Uehara JA, Nadel JA, Boushey HA. Lower threshold $C$ and greater bronchomotor responsiveness of asthmatic subjects to sulphur $\Rightarrow$ dioxide. Am Rev Respir Dis 1980;122:873.

34 Jorres $\mathrm{R}$, Magnussen $\mathrm{H}$. Airways response of asthmatics after a 30 min exposure, at resting ventilation, to $0.25 \mathrm{ppm} \mathrm{NO}$ or $0.5 \mathrm{ppm} \mathrm{SO} 2$. Eur Respir f 1990;3:132-7.

35 Pope CA. Respiratory disease associated with community air pollution and $\overline{\bar{C}}$ steel mill, Utah Valley. Am $\mathcal{F}$ Public Health 1989;79:623-8.

36 Takafuji S, Suzuki S, Koizumi K, Tadokoro K, Miyamoto T, Ikemori R, et al. Diesel-exhaust particulates inoculated by the intranasal route have an adjuvant activity for IgE production in mice. I Allergy Clin Immunoles 1987;79:639-45.

(Accepted 6 October 1992)

eventually found to have an ectopic pregnancy whenc she failed to abort. She has been excluded from furthero consideration.

Eight patients aborted with mifepristone alone. Of the 51 remaining patients, 43 aborted after taking misoprostol $600 \mu \mathrm{g}$ and five more aborted aftero receiving a second divided dose of $600 \mu \mathrm{g}$ misoprostol. In three patients the treatment failed, and they under- $\mathrm{C}$ went evacuation of the uterus under general anaes- $c$ thesia. Exploratory curettage was performed in twoळ other patients at 14 and 22 days after treatment with misoprostol, but no products of conception were obtained.

The median time from administration of misoprostol $\vec{c}$ to abortion was 4 (range 1-11) hours. The mediane duration of bleeding after abortion was 10 (2-22) days. There were no cases of infection, and no patiento required antibiotic treatment. Side effects from misoprostol treatment (nausea, vomiting, and diarrhoea) were few: antiemetic drugs were given to five patients, and diarrhoea was reported by seven. Thirty nine women did not ask for any pain relief, 13 requested oralō analgesia, and seven required parenteral analgesia.

\section{Comment}

The medical management of induced abortion is now established practice, and several centres haveo developed considerable skill in using mifepristone with a variety of prostaglandin analogues..$^{1-4}$ We have showno the clinical feasibility of managing missed abortion and anembryonic pregnancy medically without resort too surgery or anaesthesia. Patients' perceptions at this early stage of development of the method are positive but need to be assessed more thoroughly, particularlyo in relation to the alternatives. The implications in terms of resources are considerable since if this methodo became standard practice a major part of emergencyew work in gynaecology would be removed from the operating room and could be managed at times more? convenient to patients and staff.

1 UK Multicentre Trial. The efficacy and tolerance of mifepristone and prostaglandin in first trimester termination of pregnancy. $\mathrm{Br} \quad \mathrm{f}$ Obste Gynaecol 1990;97:480-6.

2 World Health Organisation Task Force on Postovulatory Methods for Fertility Regulation. Termination of early human pregnancy with RU480 (mifepristone) and the prostaglandin analogue sulprostone: a multicentre randomized comparison between two treatment regimens. Hum Reprosk randomized

3 World Health Organisation. Pregnancy termination with mifepristone anc gemeprost: a multicentre comparison between repeated doses and a single gemeprost: a multicentre comparison between

4 Norman JE, Thong KJ, Baird DT. Uterine contractility and induction of abortion in early pregnancy by misoprostol and mifepristone. Lance? 1991;338:1233-6.

(Accepted 23 October 1990) 